\title{
The Rewriting of Mythology (Remythology) and Decolonization in Eka Kurniawan's Man Tiger
}

\author{
Annisa Widyawati Fathonah \\ School of Humanities, The University of Auckland, New Zealand \\ Email: annisawidy@gmail.com
}

\begin{abstract}
This article examines the rewriting of mythology (remythology) in Eka Kurniawan's magic realism novel titled Man Tiger (2004). The discussion particularly explores how the remythology of the Indonesian myth of manusia harimau responses to historical references that are embedded in the narrative. I found that remythology in the novel is used to replicate people's voice, and by using that voice, the Indonesian nation attempts to decolonize itself from colonization and to epitomize a resistance against postcolonial powers. The myths surrounding manusia harimau in the novel further provide references to Indonesia's identity that is located between two separate identities, the indigenous and the colonial, which comprise resistance as well as resilience. By using various local mythical frameworks, Eka Kurniawan addresses the complexity of the Indonesian nation which constitutes an acknowledgement, and an interpretation, as well as a response to the past in order to form a resilient present.
\end{abstract}

Keywords: Eka Kurniawan; decolonization; Indonesian mythology; remythology

\section{INTRODUCTION}

In 1995 Keith Foulcher stated that modern Indonesian literature is both a product and constituent of a nationalist movement and a nation-state. It is a body of writing that positions itself in relation to the nation, and its claim to speak on behalf of the nation involves the link between that of a postcolonial nation and the question of the national identity of the country. As a country that suffered under Dutch colonialism for three hundred and fifty years ${ }^{1}$, the trace of colonialism in Indonesian literature is depicted as part of its identity - the identity that was pursued "in a new, non-colonial, not postcolonial, language" that is the Indonesian language or Bahasa Indonesia (Foulcher, 1995: 150). According to Foulcher (1995), Indonesian authors in the colonial era tried to define a cultural identity that incorporated the colonial legacy, while transforming it in the name of an emergent Indonesian nationalism. The legacies of the past infused their literary characters who struggled to take on the possibilities of life in the new social and cultural order. Indonesian people, as depicted in their work, sought to give form to life amid the radical transformations brought about by the colonizer's culture.

What is the nature of Indonesian literature today, decades after the proclamation of independence, where technology and globalization are the benchmarks of modernity? Indonesian scholar L.G. Saraswati Putri (2016) suggests that, despite the fact that freedom of speech has been celebrated after the reformation era, the recent Indonesian literary works not only celebrate, they also challenge, problematize, and seek to inspire the present generation. One of the major figures in this literary scene is Eka Kurniawan, an Indonesian author whose writing is known for its openness to ideas and for challenging the norms. Benedict Anderson (2015) referred to Kurniawan as a modern Indonesian litterateur who has a many-sided originality and seamlessly melds the old and the new. According to Anderson (2015), Kurniawan seems to avoid political judgment and instead occupies a more ambiguous positioning, using magic realism to combine 
history and mythology in a postcolonial examination of society. In his first novel Beauty is a Wound (2002), Kurniawan does not hesitate to raise the issue of rape and sexual abuse although such discussion is taboo in Indonesia. Whereas in his next novel Man Tiger (2004), in a dire narrative tone, he portrays the life of the Indonesian people decades after the country gained its independence.

In an interview, Kurniawan explains the genre of Man Tiger:

"This is a campur aduk [hodgepodge] novel, a psychological novel with the aspects of the mythology of manusia harimau or tiger people, with metaphors about politics."

As stated by Kurniawan himself, the phrase campur aduk appropriately captures his literary style as he does not set a limit to a social, cultural, or political literary discourse when he writes. Instead, he employs various elements that exist within the Indonesian society and combines them into one meaningful narrative, creating political and historical allegories. Such a combination creates a multi-layered richness in his portrayal of urban Indonesia. This style allows readers to focus on the numerous meanings within his stories - meanings especially identifiable by Indonesian readers as his writing embodies magic realism mixed with "supernatural elements from Indonesian folklore and myth and the techniques of Indonesian storytelling traditions" (Cheah, 2017: 100).

Global critics put his novels generally into the magical realism category (Cheah, 2017; Anderson, 2015) and particularly into the decolonizing type of literature. According to Wendy Faris (2004), magic realism opens a new decolonized space for narrative, "one not already occupied by the assumptions and techniques of the European realism" (Faris, 2004: 135). This notion is parallel to Eka Kurniawan's novels, including Man Tiger, which seek to decolonize the Indonesian nation through the rewriting of mythology, or also called as remythology. For contemporary writers, remythology is a concept often used to address local mythology that is relocated in an urban setting. It is not a branch of literary studies, but a concept that simply breaks into two English words that are 're' (prefix meaning 'again') and 'mythology'. For literary critics, this concept offers an in-depth exploration into the way mythology, which is usually told orally and passed down through generations, can be rewritten in a modern setting. Henceforward, I refer to remythology as the mythology that Kurniawan derives from an actual Indonesian mythology. This type of remythology that he uses highlights historical events and resistance against postcolonialism.

Kurniawan notes that he draws on his stories including the one in Man Tiger from myths about spirits, supernatural elements, and narratives from Hindu epics, such as, the Mahabharata and Ramayana. These supernatural elements, although they might be absurd for western readers, represent the way of life for most Indonesians. In the novel, the supernatural elements of mythology appear as the root of the Indonesian people before the western world came and are the main device to deliver didactic parables. Kurniawan narrates mythology in the novel alongside historical references and makes them equal in terms of literary engagement. His narrative style seems to agree with Michael Herzfeld who suggests that history and myth are "equally meaningful and all variations of both are valid within their own context" (in Harnish, 2006: 46). Mythology and political history in Kurniawan's writing are tangible. By drawing on mythology to provide a socio-political discourse, Kurniawan invokes a frame of meaning and a pattern of identity that the reader will recognize.

Located in urban Indonesia, the novel Man Tiger focuses on a single event that is the killing of Anwar Sadat. Its story further reveals why Margio brutally kills Anwar Sadat from a third-person point of view. With a seemingly simple storyline, Kurniawan addresses postcolonial issues and employs the mythology of manusia harimau or tiger people (tiger: harimau, man: manusia) within the narrative. The use of that mythology is arguably Kurniawan's technique to narrate history using Indonesian local, indigenous voice.

In this article, I examine the rewriting of Indonesian mythology (remythology) of manusia harimau in Eka Kurniawan's Man Tiger. I particularly explore the social and political allegories as portrayed by remythology and how the remythology concept appears as a decolonizing narrative device. To analyse the novel, I employ a close reading technique, which, according to Edgar Roberts (1991), gives a chance to exercise general perceptions and knowledge as a reader, while keeping close to the text and its interpretations.

My reading of Man Tiger sees the Indonesian mythology of manusia harimau, which Kurniawan relocates in a contemporary setting, as a narrative device that creates social and political allegories. These allegories further encompass a postcolonialism discourse. I used various studies regarding magic realism and mythology, including those by Wendy Faris (2004) and Mircea Eliade (1963), among others. According to Faris (2004), magic realism develops an indeterminate space of the colonial 
encounter, creates an area for decolonizing narrative, and counters colonial paradigms using local vocalic power. Meanwhile, as per Mircea Eliade (1963), myth is an act of preserving the existence and culture of the people by 'renewing the world' through myth. Renewing the world refers to constantly using traditional features to live our life_-'renewing' means continuing to preserve while 'the world' refers to tradition. I applied these studies in my analysis and had them assist my interpretations.

The discussion section in this article is divided into one main heading and two sub-headings. The main heading covers the introduction to the magic realist nature of remythology in Man Tiger. It is then followed by two sub-headings that provide an in-depth discussion about remythology as cultural decolonization and power resistance against postcolonial powers.

\section{REMYTHOLOGY IN MAN TIGER, THE MAGIC REALISM NOVEL}

Wendy Faris (2004) classifies a magical realist text into five characteristics, which are irreducible element, presence of the phenomenal world, merging realms, unsettling doubts, and disruptions of time, space, and identity. Eka Kurniawan's Man Tiger (2004) embodies these characteristics so that it can be called as a magic realism novel. Meanwhile, the novel's technical and narrative aspects bring about postcolonialism discourse so that it can fall into the decolonizing type of literature. In this section, I examine Man Tiger using Faris' characteristics of magic realism and I also explore the decolonizing nature of the novel.

According to Faris (2004), the irreducible elements in magic realism literature is something that we cannot explain using the laws of universe formulated by the western society. This means that a story may seem logical to some people familiar to the magical framework but it may not seem so for people, especially those coming from the western society, who are not familiar with it. Man Tiger falls into this characteristic because its magical stories and characters, such as supernatural tiger and genies, cannot be explained according to the western knowledge paradigm. The mythical framework of the novel provides a familiarity especially to Indonesian readers, but not to global readers. In the light of disruptions of cause and effect and mythical elements of the stories, the real that the Indonesian people know of may seem amazing or even ridiculous to global readers.

In addition, Man Tiger provides descriptions that give details to a strong presence of the phenomenal world. These realistic descriptions of mythical events create a fictional world which resembles the one that we live in. Freed from traditionally mimetic narrative, these descriptions turn the Indonesian mythology of manusia harimau in the novel, which is derived from the real world, into a fictional story that seems as real as the one in our world. Faris (2004) further defines magic realist text as a work that serves contradictory understandings of events, which may lead to the unsettling doubts experienced by the readers. What is central is the question of belief that points to the cultural systems within the narrative. As the readers have different beliefs and cultures, they may have doubts in the stories and thus show less interest in them. Man Tiger as a magic realist text offers this possibility of unsettling doubts since its stories vividly embody mythical elements.

The merging realms in Man Tiger are captived between two worlds, the human and the animal, which are belonging to one another. The human realm in the novel is the world in which Margio, the main character, and other people in the fictional town Halimunda reside, whereas the animal realm belongs to the world where supernatural tiger and genies exist. In addition to merging the human and animal worlds, Man Tiger also disturbs the ideas about time, space, and identity. As per Faris (2004), magical realism reorients not only our habits of time and space, but also our sense of identity. Man Tiger gives these disruptions through the depiction of jumping timeline and radical multiplicity of space. The novel has several settings of time that jump from one another. This is shown when the novel opens as Anwar Sadat is murdered, and the stories tell about the time before and after the time of his murder interchangeably. There are also multiple spaces in the novel disrupting the real world. Those spaces are the real space, in which the fictional characters live in, and the magical space, in which mythical creatures reside. In terms of identity, there is a major disruption to the identity of Margio as a main character. The novel depicts him as either a man who actually has a supernatural tiger conceived within him or a man who imagines a tiger living inside his body.

The above characteristics serve to support Man Tiger as a magic realist novel, while its historical references introduce readers to the decolonizing nature of the text. According to Faris (2004), if we focus on the references in a magic realist novel-including historical references - in addition to its magical or mythical description, "we may witness idiosyncratic recreations of historical events, but events grounded firmly in historical realities, often alternate versions of officially sanctioned accounts" (Faris, 2004: 15). In Man Tiger, the historical aspects in the descriptions specifically differ from its 
mythical components although both are related. Their combination, however, implies that historical events and myths are both essential aspects to our collective memory.

Postcolonialism discourse coming from the Indonesian people's collective memory is pervaded in Man Tiger. Cultural decolonization in the form of remythology emerges as a response to Indonesia's postcolonial memory, and by using the myths surrounding manusia harimau, remythology appears as a concept that counters colonial powers and demonstrates the domination of local cultures over western penetration. The following sections provide the discussion regarding these notions that I propose. The first section examines remythology as a cultural decolonization device, while the second section discusses remythology that demonstrates a power resistance against traditional magic and colonial myths.

\section{Remythology as Cultural Decolonization}

Kurniawan uses mythology, which the Indonesian people normally encounter, as a form of cultural identity owned by the indigenous people. He does not use the original version of the mythology. Instead, he deconstructs well known mythic frameworks in order to highlight contemporary socio-political clashes. This writing technique that Kurniawan employs can be classified as remythology or the act of rewriting mythology. In Man Tiger, the mythology that Kurniawan deconstructs and rewrites is the Indonesian mythology of manusia harimau, which is narrated along with several Indonesia's historical events. His version of myth emerges as a form of native identity reflecting the Indonesian people, owned long before the colonizers came, that collide with the culture that the colonizers brought about. His version of myth, therefore, seems to embody the cultural memory of the Indonesian people. Astrid Erll (2006: 2) suggests that cultural memory provides "the relationships between such phenomena as ancient myths and the personal recollection of recent experience." Similarly, Kurniawan's rewriting of mythology appears as the re-invention of native culture and collective memory in which the recent history of Indonesia is comprised.

In the novel, Kurniawan employs the Indonesian mythology of manusia harimau while, at the same time, narrating Indonesia's social and political events. Many regions in Indonesia, such as Sumatra and Java, own the tiger mythology and each of the versions has their own plots and characters. The main character in all versions, however, is a tiger who often acts as a protector.
Kurniawan employs this tiger character in Man Tiger as a decolonizing narrative device embodied by a human character whose name is Margio. This relocation of the tiger mythology appears to undermine colonial paradigms brought about by the colonial context, and operates using the local beliefs rather than the western material progress. Timothy Brennan (1997) suggests that this kind of literary technique presents a mixture of the miraculous and the mundane of existing cultures that appears at once religious and strangely utilitarian. In those cultures which the colonial realism exists, the local culture fights for an authority for themselves. Kurniawan's rewriting of the tiger mythology in Man Tiger exemplifies the idea that battles the control over territories in both actual and textual and are motivated by the hidden presence of the sacred of myth. The sacred aspect is comprised within a defocalized narrative against postcolonialism.

The postcolonial discourse in Man Tiger coherently stretches from the late colonial period to the early time of the Suharto regime under the shadow of the remythology of manusia harimau. The remythology does not point to a particular historical event. Instead, it highlights different historical events and represents the power of local traditions. Throughout the key historical events that are explored within both the traditional and contemporary mythic frameworks, the characters of Man Tiger struggle with their personal problems amidst a tumultuous political context. This collision of myth, postcolonial discourse, and personal challenges highlight the different kinds of encounters between the indigenous Indonesian culture and colonialism. Aparna Halpé (2010: 28) explains, that the myth that is represented in the fiction is a means by which to compensate "the erasure of indigenous narrative practices and is reconstructed in relation to particular notions of cultural identity". Based on this theoretical stance, the remythology of manusia harimau in Man Tiger does not only reflect a resistance against colonial and postcolonial power. They also represent a certain resilience in defiance of the introduction of colonial culture.

Because the novel takes place after formal colonialism has ended, the Indonesian cultural identities are depicted against the backdrop of the legacies of colonialism. These legacies are everything that the colonizers have left behind, which includes the physical legacy, such as, the architectural buildings and the system legacy, such as, the repression that is associated with the system. The current 'enemy' for the Indonesian people is not the colonials per se, rather it is the ideas and systems that the colonizers have left behind. Ariel Heryanto (2018: 609) explains that, since independence, 
Indonesia has "deliberately worked in earnest not only to reject much of its colonial cultural parentage, but also to invent a completely new and 'native' culture". In the novel, such acts of inventing culture can be evidenced in the unconscious adaptation of the colonial legacy and the projection of the local traditions. The novel therefore emerges as a medium to reflect on the culture and the history in order to invent a new, postcolonial situation. Astrid Erll (2006) suggests that literature "establishes a memory of its own in the form of intertextual relations that give new cultural life to old texts" (Erll, 2006: 113). Parallel to that notion, Kurniawan's remythology in Man Tiger introduces a local aspect into a postcolonial narrative to portray a new culture that the Indonesian people have invented. In that new culture, the local and colonial identities live with each other as a result of cultural collision.

Remythology in Man Tiger provides a space for the encounter between the indigenous and colonial culturesone that is native to the people and the one imposed by western society and brought about by colonialism. The novel further offers an area for decolonizing narrative using the remythology of local myth, and for countering colonial paradigms using literary allegories. The use of remythology along with historical events is arguably to show the dominant power of local culture against the colonial culture, depicted by the colonial building and samurai sword in the novel. In this way, remythology can be classified as the act of cultural decolonization. Faris (2004) suggests that this kind of decolonization, which remythology may take a part of, represents the world that western readers and their communities lose their narrative authority of invested realism. The narrative authority is therefore passed on to the local people whose mythic cultures represent their identities.

Remythology in the novel further appears as an indigenous identity of the Indonesian people before the colonial powers came to occupy. Bill Ashcroft et al. (2013), explains that, in many postcolonial societies, a pre-industrial population "had its imaginative life rooted in a living tradition of the mythic, the legendary and the magical" (Ashcroft et al., 2013: 148). Indonesia has this imaginative life, too, as demonstrated by the myth and folklore in which their local values are encapsulated. These values encompass the indigenous identity of the Indonesian nation that had to be compromised with the incoming colonial culture. Following this notion, the remythology of manusia harimau in Man Tiger conveys the root of the people and asserts the new, postcolonial identities, and in those identities resistance is found.

\section{Remythology as Power Resistance against Traditional Magic and Colonial Myth}

Kurniawan's rewriting of the manusia harimau mythology in Man Tiger explores the identity politics of the Indonesian people at different historical moments, and identifies their resilience as well as their resistance to their colonial legacy. The remythology further emerges as power resistance not only against traditional magic myths but also colonial myths. This means that the rewriting of Indonesian mythology in the novel extends throughout the dismissal of traditional myth stereotypes and the representation of traditional myth which may seem absurd to those unfamiliar with it. The rewriting also demonstrates a countering prevalence against the colonial myth brought to the nation along with colonial culture. This countering widespread presence pervades how the local voice, as portrayed by the myths surrounding manusia harimau in the novel, attempts to extricate itself from colonial powers including colonial myth and culture. This power resistance is poured into the text, mirroring the real world and subtly depicting the Indonesian nation.

Margio, the main character in Man Tiger, is a manusia harimau or tiger man whose supernatural power is concealed within him. His transformation into manusia harimau presents an allegory that explains Indonesia's resistance against colonialism, and such an allegory is packed in a magical story and uses myth as the medium of cultural memory. Margio, who "became known as the herder, with his powerful strides and ruthless spear" (Kurniawan, 2014: 7), not only represents the resistance he is also representing a mythical element possessed by indigenous Indonesians. Taking place decades after the formal colonial era ended, Margio goes through a familial struggle that ends up tragically and his life story further conceals something deeper in the subtext. He represents something more than just a man who is in pain. His life parallels that of his nation during the postcolonial era, a nation seeking revenge against its former colonizers. His character is a symbol of reciprocity and he serves to represent a collective response to colonialism, for fiction can be treated as a historical document that is a product of and by the people (Armstrong, 1990). Fiction can capture history in a creative way and, therefore, the imaginative work of one person, including that of Kurniawan, may reflect the thoughts of his society at the given time.

Eka Kurniawan uses references to myths in Man Tiger to reveal Indonesia's cultural memory as a colonized country. He does not blatantly describe the main character, Margio, as an alteration of the myth. 
Instead, he simply describes him as a man who conceals a supernatural power similar to that of a tiger, however, his character resonates with aspects of the manusia harimau mythology. Through the employment of the manusia harimau mythology, Kurniawan provides an allegory to illustrate postcolonial resistance- the resistance embodied by Margio. The use of the Indonesian mythology of manusia harimau in the novel can be interpreted as a preference to interpose Indonesia's cultural legacy to respond to its colonial legacy, as Franco Moretti describes myth as "the sign and instrument of symbolic resistance to western penetration" (247-248). This is also supported by the depiction of the tiger in the novel which expresses a local symbol. The tiger concealed within Margio is a white, female tiger and, according to the Indonesian local culture, this suggests a renowned strength, majestic fierceness, and protection.

Tiger or harimau is a meaningful animal in Indonesian culture. It is seen as great and brave, and it is also savage. While on the one hand the tiger has been described as the source of death and fear by the Indonesians, on the other hand, the tiger presents a picture of fearful beauty with a velvety step and undulating movements (Kipling, 2016; Denis, 1964). Anthropologist Robert Wessing notes, the power of the tiger as a symbol in Indonesia lies "in the ambiguous relationship with man. This relationship parallels the opposition between men and beasts, civilization and nature, controlled and uncontrolled power" (Wesing, 1995: 1). The ecological niche occupied by the tiger often overlaps with that of man. Useful as a depredator of crop-damaging animals, the tiger may also be a disruption as a rider of livestock and dangerous to human life. Even though the forest where the tiger lives is a source of danger, it is also a place where there are sacred trees and supernatural powers that are both good and evil (Spencer, 1966). Wessing explained that it is due to this ambiguous relationship between the tiger and men that may have attributed to the symbolic use of the tiger (Wessing, 1995). The tiger relates to man as a wild forest creature relates to a civilised animal. However, the two are in partial competition while simultaneously in a symbiotic relationship since their ecological niches can overlap. Frank Hamel (1969) wrote that while the tigress' courage, strength, and cunning may be highly regarded in times of trouble, the tigress may also be feared. Because of this image, Peutua Gam Masen, an Acehnese ${ }^{2}$ leader in the war against the Dutch, had to be captured because he was regarded as a ruler of tigers thus he had great influence (Zentgraaff and Van Goudoeve, 1947 as cited in Wessing, 1995).

Meanwhile, in Sumatra's community culture, the Sumatran tiger is a highly dignified and charismatic symbol. This is especially so because the Sumatran tiger is an indigenous animal found only on the island, thus becomes a marker of the identity of the people. The Sumatran community has always had a mystical relationship with tigers and they were considered more as gods and spirits than animals (Bakels, 2009). C.W. Watson (1992) notes that Kerinci particularly has a reputation throughout Sumatra and Malaya as a remote and mysterious region, where the forces of malign magic exercise a strong influence. The Malays point specifically to Kerinci as the source of manusia harimau (tiger people), called as cindaku in this region, nevertheless only some men have the ability to become one. These weretigers are called jadi-jadian (imitation; apparition) and they do not turn into a tiger rather they are possessed by the spirit that is familiar to a tiger (Wessing, 1986). In 2017, a local wrote that even today, the Sumatran tiger bears two meanings for the Kerinci community, one is as a native fauna and second is as nyiek or ancestor who owns the land. As fauna, the tiger is considered to be part of nature that lives alongside humans. It is important for humans to not disturb the habitat of the fauna, and vice versa. If one disturbs another, the balance of nature will be damaged. Whereas as nyiek, the tiger is seen as a living being that came and resided in Kerinci before civilisation. Humans must respect tigers because they were on the land first and thus represent the origin of the land.

Interestingly, the mythology of manusia harimau in Man Tiger is not similar to any of the original versions in Java and Sumatra. The mythology in the novel therefore emerges as an imagined deconstructed mythology that Kurniawan relocates in a fictional story behind the backdrop of postcolonialism. This postcolonialism context may not seem obvious for readers who are unfamiliar with the Indonesian socio-political history. However, for some, if not most, Indonesians, including myself, the history and the local aspects are evident. While Margio's character especially seems to be based in general on the manusia harimau mythology, it resonates in particular with that of the Kerinci community in Sumatra, which is the cindaku mythology. A cindaku, as how a tiger man is called in Kerinci, protects the balance of nature from external and internal threats. Margio as a main character shows the same responses to colonial threats by using his supernatural power. In this way, he represents the indigenous Indonesians who resist any abuse or provocation which, in this context, is administered, inflicted or meted out by colonial and postcolonial powers. While Kurniawan does not make these connections explicit, from the perspective of an 
indigenous Indonesian, including from my perspective, these connections are quite obvious.

Margio's character indeed resonates the most with the myth of cindaku from Kerinci in Sumatra. This is especially evident by the fact that Margio receives power from his grandfather. According to the cindaku legend, the power to become a cindaku is inherited from one's ancestors (Wessing, 1986: 96-97) except not everyone from the family line can be one, as only the person with special spiritual abilities will be selected.

According to Ma Muah, the tigresses lived with their owners and guarded them against all dangers. She said that Grandpa was among those who kept a white tiger . . . He had often heard of his grandfather's prowess, and that of elders in other hamlets: how they resisted Dutch efforts to abduct the best young men for forced labour in the Land of Deli. Bullets had no effect on them, nor did the samurai swords of the Japanese . . They even expelled the gangs of Darul Islam guerrillas roaming the jungle" (Kurniawan, 2014: 41-42).

As in the original legend, Margio inherits power from his grandfather who uses his power to fight against colonizers. Many other men in Halimunda also had the power to become a cindaku, and they went to war to defeat the colonials and other threats from within the nation. As juxtaposed by this part of the story, cindaku becomes the symbol of resistance.

The men in the novel become one body with and are guarded by the tigers. They come together to defend the mother land, which appears the evident of the sociological function of myth. As per Campbell (2011), myth as a sociological function is about "supporting and validating a certain social order" and becoming one with nature. Humankind has to learn to get back "into the wisdom of nature and realise again our brotherhood [sic] with animals and with the water and the sea" (Campbell, 2011: 40). Cindaku in the novel portrays this balanced brotherhood [sic] with animals. Their brotherhood is to maintain the surroundings' safety and to help each other if one needs a hand. In this sense, the myth emerges as a social order produced by the people, with the role to ensure that humanity acts as one with nature. Therefore, humans and animals must protect each other and become the consciousness, the eyes, and the voice of the earth.

Ma Muah said that this was all because of the elders' elemental friendship with the tigresses, who became family through wedlock (Kurniawan, 2014: 42).
The power to become cindaku cannot be acquired by Margio while his grandfather is still alive. This indicates that myth is a rite of renewal and that death is the beginning of a new power that will soon be possessed by the younger generation. According to Eliade (1963; $45)$ the only way "to renew the world is to repeat what the Immortals did in illo tempore, [it] is to reiterate the creation". Death constitutes a new situation, which must be accepted and assumed without deprecation. Death can also be "botched as a battle can be lost, as psychic equilibrium and joy in living can be destroyed" (Eliade, 1963: 32). The passing down of power as cindaku is a form of beginning a new world that cannot be avoided. This new world, in which Margio lives, is where colonialism is no longer alive since it is defeated by the people in the previous time. Social order is thus reproduced and reincarnated. This forming of a new world and time also means the re-creation of a new culture which combines indigenous and colonial legacies. Myth then exists to remind people of their origin, to become a moral compass, and to maintain a balance with nature. As the power to become a cindaku is passed down, the moral code of being at one and in harmony with nature is inherited, too. Margio seems to pursue this harmony all his life, given his eagerness to possess the power that his grandfather had. One morning, he finally gets to meet the supernatural tiger, which completes his search for his other half.

The tigress had come to him, lying beside him on the surau's warm rug, while the universe outside froze. As his grandfather had said, the tigress was white as a swan or a cloud or cotton wool . . . He wrapped his arm around his neck, embracing her and feeling the warmth of her fur against his body ... The tigress was there, a part of him, the two of them inseparable until death" (Kurniawan, 2014: 43).

Margio's first meeting with the tiger looks like some kind of wedlock ritual, unifying the human and supernatural tiger so that they are inseparable. This ritual marks the entrance to a new world for Margio because there is a belief in the "possibility of recovering the absolute beginning, which implies the symbolic destruction and abolition of the old world" (Eliade, 1963: 50) since the world of his grandfather, in which colonialism existed, is now gone. Now that Margio is viewed as half a tiger, he lives in the postcolonial world and his power will not only be used directly against the colonizers, but also to counter postcolonial threats.

Margio eloquently conducts a violent resistance against what he considers a threat and uses his power 
to deal with a familial problem. Once he finds out that his dearest mother's male paramour, whose name is Anwar Sadat, uses her only for sexual pleasure, Margio gets so enraged that the tiger within him takes over his consciousness. His mother, Nuraeni, has been involved in an abusive and loveless marriage and feels she has found real 'love' with Anwar. The man, however, does not cast her in a sympathetic light. He does not care about her and seemingly uses her only for her body, even after Nuraeni gives birth to his illegitimate daughter who dies a week after she is born. Margio knows that the infant child belongs to Anwar Sadat. He then comes to the man's house to ask if he truly loves her. After Anwar Sadat replies in the negative, upon hearing his answer, Margio murders him by brutally biting his neck. This murderous act is an instant reaction caused by the unbalanced situation in his family. Anwar Sadat has hurt a family member his mother, Nuraeni - therefore, the supernatural tiger within him takes over and attacks. This brutal act seems to fictionalise Robert Wessing's argument that as in all tiger beliefs, while the tiger is in the system, the tiger is good, guides, and guards and the like (Wessing, 1986). However, if the tiger is outside the system, he is a source of danger. Similarly, if Margio's environment is within the rules of custom, he is predictable and thus good. But if these rules are transgressed, as exemplified by Anwar Sadat's irresponsible and immoral act, then Margio becomes a source of danger.

Anwar Sadat shook his head nervously, and his reply came out brokenly . . . "Besides, I don't love your mother" ... That was when the tiger came out of Margio, white as a swan (Kurniawan, 2014: 172).

Nuraeni is the sole reason for Margio's violence. The 'mother' figure here is significant because if we extend her symbolically she becomes the embodiment of Indonesia as a nation. The concept of 'mother' is parallel to colonised Indonesia before Independence at a time the country was manipulated by a more dominant power that was from the outside. Indonesia, as Ibu Pertiwi or Mother of the Land (ibu: mother; pertiwi: land), is considered as a mother from whom all Indonesians are born. Ibu Pertiwi is the allegory of tanah air or land and water, and refers to earth and nature spirits as a life giving mother.

In the colonial era, Ibu Pertiwi or the Mother of the Land was suffering because of colonialism. This suffering is epitomized in the novel as Nuraeni, the mother, who is abused and suffers at the hands of two dominant male figures. Her husband, Komar bin Syueb, often beats her - the beating which she calls a 'slow death' — and
Anwar Sadat, to whom she goes to seek consolation, uses her only for sexual pleasure. Komar bin Syueb can be interpreted as a monster from within the family and makes the link to President Suharto in independent Indonesia, who also seems like a monster from within the nation. During the Suharto regime, many cases of human rights violation occurred (Melvin, 2018; see also Simons 2000). Suharto, the dictator leader, was said to be responsible for the death of more than half a million political opponents, the censorship of the media, and the banning of political dissent (Amnesty International, 1994). These abuses were seen as raping the country, and were integral to Komar bin Syueb in the novel who is said to be the husband who 'rapes' his wife. Margio, his son, is described as "a child of domestic rape, yet the boy seemed to be an infinite consolation" (Kurniawan, 2014). Marital rape can be seen as an abuse from within.

In the novel, abuses of power are portrayed by the dominant men, Komar bin Syueb and Anwar Sadat, over the weak mother, Nuraeni. These men abuse Nuraeni just as the colonizers and Indonesia's dictator did, using their dominant power to control Dutch East Indies (now Indonesia). The violent treatment and power manipulations from which Nursaeni suffered reflects what Indonesia has been through during and after colonialism. Margio's attack can be interpreted as the act of defending the mother's pride that overshadows Ibu Pertiwi or the Mother of the Land. Tanah air or land and water, on which Ibu Pertiwi stands and Margio symbolically defends, seems to be not just land. It is something that Campbell (2011) refers to as 'the blood of our ancestors' whose reflections in the waters "tell of events and memories of the life of the people. The water's murmur is the voice of [the] father's father" (Campbell, 2011: 42).

Margio's plead for Anwar Sadat's compassion for Nuraeni reflects the demand for empathy. He expects Anwar Sadat, who is parallel to the colonizer, to be compassionate towards Nuraeni as the woman suffers and hurts. His plead can also be seen as a result of the deception by Anwar Sadat's dominant power. Anwar Sadat treats Nuraeni as if he really cares about her, making both Nuraeni and Margio believe that he really cares, while in fact, he does not. This deception and manipulation are an obvious example of the power of abuse just like the abuse that the colonizers did to Indonesia.

In colonial Indonesia, such a manipulation also transpired in Kerinci, where the myth of cindaku originated. The Dutch invasion of Kerinci in 1903, according to a study based on indigenous oral history, was actively supported by a large population. The locals saw the colonial government as a 'stabilising force' and 
'hoped the Dutch would bring an end to inter-village disputes and order into the area which was renowned for its lawlessness' (Watson, 1992). This expectation is ironic because the Dutch came to Kerinci to expand their colonial territory and to find more places to produce spices for them (Henley, 2004; Locher-Scholten, 1994). Parallel to this, Margio's rage towards Anwar Sadat in the novel shows resistance against the manipulation that people in Kerinci had experienced. Margio's murderous act is one of a defensive nature and was provided by the inheritance of an indigenous culture. The fact that he bit Anwar Sadat's neck can be seen as an organic way of showing a defensive nature, since he does not use weapons but his body.

This defensive quality is also what builds the Indonesian people today. Indonesia as a modern nation can be viewed in parallel with Margio, the half-manhalf-tiger, which protects itself from being abused and manipulated by foreign powers. Manusia harimau or cindaku seems to be a characteristic of the Indonesian people: indigenous, cultural, and owned by the native aspect of the place. This characteristic is met with the legacies of the colonial past which the Indonesian people have to live with, as portrayed by the colonial building, the railway station, and the samurai sword. This collision of the colonial and indigenous legacies in Indonesia lead to the creation of a new culture. In the novel, this new culture is reflected by the co-existence of the town Halimunda, which had been through years of colonialism, and the wildlife in the forest, where the mythic legend is concealed. The Indonesian people's acculturation has gone through numerous acts of resistance to counter the colonial powers. An allegory of this resistance is portrayed in Kurniawan's Man Tiger by the myths surrounding manusia harimau, embodied by Margio, the son born from coercion and violence.

\section{CONCLUSION}

Eka Kurniawan's Man Tiger is a magic realism novel whose supernatural stories are based on the Indonesian mythology of manusia harimau. The rewriting of mythology (remythology) is not always pointed out explicitly in the narrative, however, the mythical frameworks, which may seem absurd for western readers, are easily recognised by the Indonesian readership. Using this type of remythology, Kurniawan subtly explores Indonesia's historical events in a postcolonial examination of society, supported by several key historical events which include Dutch colonization. Those events are presented in the narrative behind the shadow of the remythology, just as in Indonesian shadow puppetry shows (wayang) with Kurniawan as the puppeteer. Such a combination of remythology and history creates a multilayered richness in the portrayal of urban Indonesia. By drawing on remythology to provide a socio-political discourse, Kurniawan invokes a frame of meaning and a pattern of identity of the Indonesian people, which is arguably located between two identities: the indigenous and the colonial. In the novel, various local mythologies are depicted as an indigenous inheritance that embodies indigenous resistance to colonial encounters.

Remythology in Man Tiger further demonstrates a power resistance against traditional magic and colonial myth - the myth that was brought to Indonesia along with colonial cultures. Remythology also portrays the Indonesian nation that seeks to decolonize itself from colonial powers. By relocating the Indonesian mythology of manusia harimau in a contemporary setting, the novel displays the efforts of the Indonesian people to reclaim their indigenous voice by using local traditions to counter the culture imposed by the colonizers.

\section{ENDNOTES}

1) Some scholars contest the nature of the ' 350 year of colonization' which has always been taught in schools and is printed in Indonesia's history textbooks. The Dutch came to the land, now Indonesia, in the 16th century while the country was not formed yet as a whole. The land did not even have a name as a nation and what it consisted of was not yet determined. To this day, the exact time the Dutch 'completely' colonised Indonesia is still a matter of debate (see Resink, 2012).

2) Acehnese is an ethnic group from Aceh, on the northern most tip of the Sumatra Island.

\section{REFERENCES}

Amnesty International. (1994). Indonesia: Power and impunity: Human rights under the new order. Retrieved from https://www.refworld.org/ docid/3ae6a9b9c.html

Anderson, B. (2015). Introduction. In E. Kurniawan (Ed.), Man tiger (2014). London: Verso.

Armstrong, N. (1990). Some call it fiction: On the politics of domesticity. The Other Perspective in Gender and Culture: Rewriting Women and the Symbolic, 5, 59.

Ashcroft, B., Griffiths, G., \& Tiffin, H. (2013). Post-colonial studies: The key concepts. Routledge.

Bakels, J. (2009). Kerinci's living past: Stones, tales, and tigers. From Distant Tales: Archaeology and Ethno history in the Highlands of Sumatra, Dominik 
Bonatz, John Miksic, John David Neidel, Mai Lin Tjoa-Bonatz (Ed.): Cambridge Scholar Publishing, 367-382.

Brennan, T. (1997). At Home in the World: Cosmopolitanism Now. Cambridge: Harvard University Press.

Campbell, J., \& Moyers, B. (2011). The power of myth. Anchor.

Cheah, P. (2017). Worlding literature: Living with tiger spirits. Diacritics, 45(2), 86-114.

Colombijn, F. (2002). Explaining the violent solution in indonesia. The Brown Journal of World Affairs, 9(1), 49-56.

Denis, A. (1964). Cats of the world. Houghton Mifflin Boston.

Eliade, M. (1963). Myth and reality, trans. Willard R. Trask. Prospect Heights, Ill. Waveland Press. First Published.

Erll, A., \& Rigney, A. (2006). Literature and the production of cultural memory: Introduction. European Journal of English Studies, 10 (2), 111-115.

Faris, W. (2004). Ordinary enchantments: magical realism and the remystification of narrative. Nashville: Vanderbilt University Press.

Foulcher, K. (1995). In search of the postcolonial in indonesian literature. Sojourn: Journal of Social Issues in Southeast Asia, 147-171.

Halpé, A. (2010). Between Myth and Meaning: The Function of Myth in Four Postcolonial Novels. University of Toronto.

Hamel, F. (1969). Human animals. Library of Alexandria.

Harnish, D. D. (2006). Bridges to the ancestors: Music, myth, and cultural politics at an indonesian festival. University of Hawaii Press.

Henley, D. (2004). Conflict, justice, and the stranger-king indigenous roots of colonial rule in indonesia and elsewhere. Modern Asian Studies, 38(1), 85-144.

Heryanto, A. (2018). Decolonizing indonesia, past and present. Asian Studies Review, 42(4), 607-625.

Ketika manusia dan harimau berikrar janji. (2017). Retrieved from https://beritagar.id/ artikel/laporan-khas/ketikamanusia-dan-harimau-berikrar-janji.

Kipling, R. (2016). The jungle book. Simon and Schuster.

Kisah tentang ibu pertiwi. Retrieved from https://kumparan. com/kumparannews/kisah-tentang-ibu-pertiwi

Kurniawan, E. (2014). Lelaki harimau. Gramedia Pustaka Utama.
Kurniawan, E. (2015). Man tiger: A novel. Verso Books.

Locher-Scholten, E. (1994). Dutch expansion in the indonesian archipelago around 1900 and the imperialism debate. Journal of Southeast Asian Studies, 25(1), 91-111.

Melvin, J. (2018). The army and the indonesian genocide: Mechanics of mass murder. Routledge.

Moretti, F. (1996). Modern epic: The world-system from goethe to garcía márquez Verso.

Passchier, Cor. (2007). Colonial architecture in indonesia references and developments. The Past and the Present Architecture Indonesia, Rotterdam: KITLV Leiden.

Prasetjo, A. (1996). Orde baru 31 tahun, 2,000 judul buku dibredel. Tempo Interaktif.

Putri, L. G. Saraswati. (2016). Engaged literature: An examination of social issues reflected in contemporary indonesian literature. Bijdragen Tot De Taal-, LandEn Volkenkunde / Journal of the Humanities and Social Sciences of Southeast Asia, 172(2-3), 349-368.

Resink, G. J. (2012). Bukan 350 tahun dijajah. Komunitas Bambu.

Roberts, E. V. (1991). Writing themes about literature. Prentice Hall.

Sato, S. (2006). Indonesia 1939-1942: Prelude to the japanese occupation. Journal of Southeast Asian Studies, 37(2), 225-248.

Saunders, J. (1998). Academic freedom in indonesia: Dismantling soeharto-era barriers. Human Rights Watch.

Simons, G. (2000). Indonesia: The long oppression. Springer. Spencer, J. E. (1966). Shifting cultivation in southeastern asia. University of California Press.

Watson, C. W. (1992). Kinship, property and inheritance in kerinci, central sumatra. Cellar Book Shop.

Watson, C. W., \& Ellen, R. F. (1993). Understanding witchcraft and sorcery in southeast asia. University of Hawaii Press.

Wessing, R. (1986). The soul of ambiguity: The tiger in southeast asia. Tipi Pr.

Wessing, R. (1995). The last tiger in east java: Symbolic continuity in ecological change. Asian Folklore Studies, 191-218.

Zentgraaff, H. C., \& Van Goudoever, W. A. (1947). Sumatraantjes. W. van Hoeve. 